\title{
Impact of CRM Factors on Customer Satisfaction and Loyalty
}

\author{
Choi Sang Long ${ }^{1}$, Raha Khalafinezhad ${ }^{1}$, Wan Khairuzzaman Wan Ismail ${ }^{2} \&$ Siti Zaleha Abd Rasid ${ }^{2}$ \\ ${ }^{1}$ Faculty of Management, Universiti Teknologi Malaysia, Malaysia \\ ${ }^{2}$ International Business School, Universiti Teknologi Malaysia, Malaysia \\ Correspondence: Choi Sang Long, Faculty of Management, Universiti Teknologi Malaysia, Johor, Malaysia. Tel: \\ 60-16-763-4198. E-mail: cslong_1@yahoo.com
}

Received: May 9, 2013 Accepted: June 5, 2013 Online Published: August 1, 2013

doi:10.5539/ass.v9n10p247 URL: http://dx.doi.org/10.5539/ass.v9n10p247

\begin{abstract}
This paper examined the impact of customer relationship management (CRM) elements on customer satisfaction and loyalty. CRM is one of the critical strategies that can be employed by organizations to improve competitive advantage. Four critical CRM elements are measured in this study are behavior of the employees, quality of customer services, relationship development and interaction management. The study was performed at a departmental store in Tehran, Iran. The study employed quantitative approach and base on 300 respondents. Multiple regression analysis is used to examine the relationship of the variables. The finding shows that behavior of the employees is significantly relate and contribute to customer satisfaction and loyalty.
\end{abstract}

Keywords: customer relationship management, relationship development, customer loyalty, customer satisfaction, interaction management

\section{Introduction}

Customer relationship management (CRM) is a concept for managing a company's interactions with customers, clients, and sales prospects. It involves using technology to organize, automate, and synchronize business processes. The objectives of CRM are to enhance profitability, income, and customer satisfaction. To attain CRM, many organizations use set of tools, technologies, and procedures to support the relationship with the customer to enhance sales. Therefore, CRM is an issue of strategic business and process rather than a technical one (Dowling, 2002).

The significance of customer satisfaction cannot be dismissed while happy customers are like free advertising for the company. It is necessary to put the customer at the centre of the business according to its strategies, events and processes. In fact, it is easier and more profitable to sell to present customers than to find new ones. Organizations are setting themselves strategies to ensure customer retention, and changing their employees to be more customer-focused and service-oriented (Mohsan et al., 2011).

As Baker (2003) indicates, all businesses have been affected to some degree and evolution which is happening in the global market place. Now, not only the organizations aim to satisfy the customers but they attempt to do this more efficiently and effectively than their rivals in the competitive market place to attain their goals (Kotler and Armstrong, 2011). The most important goal of an organization is to maintain customer loyalty and focus on customer centric approach in their organizational and marketing strategies (Jain \& Singh, 2002).

Bowen and Chen (2001) argue that having satisfied customers is not sufficient. This is because customer satisfaction needs to have direct impact to customer loyalty. Sivadas and Baker-Prewitt (2000) stress that there is a rising recognition that the last objective of customer satisfaction measurement should be customer loyalty. Many organizations merely categorize customer satisfaction measurement as a type of "marketing intelligence" instead of using it as a management tool to build customer service quality improvement processes and increase profit (Linnell, 2006).

\section{Previous Studies on the Relationship between Effectiveness of CRM, Customer Satisfaction and Customer Loyalty}

Khaligh et al. (2012) investigate the impact of CRM on customer loyalty and retention in the telecom industry in Iran. The data are collected from 200 Iranian telecom services users. Finding shows that commitment and vision of the management system is highly required for a successful CRM implementation. The structure of the strategy 
should be based on flexibility and explicitly of the policies especially pricing policies. These factors are very important to increase customer loyalty and benefit of the firm (Khaligh et al. 2012).

According to the research by Bhattacharya (2011), CRM is implemented in an organization to reduce cost and increase company performance, which means profitability result through customer loyalty. Indeed, in a successful CRM implementation, data are collected from internal and external source such as sales department, customer service, marketing, after sales services, procurement, and others. This is crucial in obtaining a holistic view of each customer requirement in a real time system. This information will able to aid employees to make fast and accurate decision when dealing with the customers in different areas and touch points. The finding of this study shows that the customer perception and treatment given to each customer individually able to assist in solving many customer's problems. Thus, customer satisfaction and loyalty would be achieved through a successful CRM implementation. Therefore, organization should discover different requirements of the customers and adjust their policies according to their needs to increase the firm's competitiveness.

According to the conceptual framework proposed by Faed (2010), customer relationship management amplifies the relationships of customers and competitors in a firm to increase the share of the organization in marketplace by integrating technology, procedures and people. The aim of CRM is to maintain the customers and increase their loyalty and organization profit. Customer satisfaction and pleasing are two main elements in a successful CRM implementation for retaining customer's loyalty to a firm.

Kim et al., (2003) stress that each perspective of the CRM framework is evaluated by a set of related metrics. In this regards, a case study has been carried out by Kim et al., (2003) to an online shopping company in South Korea that sales 30,000 products in 12 categories. This company ranked as $18^{\text {th }}$ online shopping mall in South Korea. Data collected through experts' interview, questionnaires and weblog analysis. Findings illustrates that, the factor which is very important to increase customer satisfaction, customer loyalty and benefits of the firm is to clear all vagueness and implicit problems that exist in the top level of strategic managements. A single and explicit language would be provided for accurate communication in an organization.

According to a study on 100 firms who are active in different area of industry such as: manufacturing, communication, financial and others, Bohling et al. (2006) develop a number of criteria to implement CRM successfully. These criteria are divided to three main groups:

1) Project focused

2) Internally oriented metrics, employees' adoption

3) Externally oriented metrics, customer satisfaction and loyalty

According to the findings, the most important externally oriented criteria are as follows:

1) verified customer influence in terms of loyalty and satisfaction

2) measureable revenue development

3) enhanced information and perception

4) measurable cost drop

5) enhanced employee efficiency

6) practice by employees

7) compliance to particulars

Wang and Lo (2004) found that CRM model is based on two perspectives. First, measures the factors related to customer behavior such as: repurchasing, cross and up selling and customer acquisition rate, and second, measures the relationship quality, such as customer satisfaction and customer loyalty (Wang and Lo, 2004). Data were collected randomly from 400 selected customers of two security companies from China. The finding shows that emotional and functional behavior of customers has positive impact on customer satisfaction and customer satisfaction has positive effect on customer behavior based on CRM elements. Finally, the result of this study shows that customer behavior based on CRM have a positive effect on customer and brand loyalty (Wang and Lo, 2004).

Zineldin, (2006) developed a triangle strategy between quality, CRM, and customer loyalty which is leading to companies competitiveness. This research was designed to measure satisfaction and loyalty of the customers based on two main conditions where the customer database information and strategy of CRM should be well structured and the capacity of the system should be enough to produce data for accurate analysis. According to the findings of the research, any changes of the quality of the services or productions in a firm over time could be used as an 
indicator to find the level of customer loyalty through a well-structured CRM strategy. If the indicators of interaction, infrastructure, and atmosphere are linked to the product and process quality, it helps the researchers to find what changes are required in CRM strategy to improve customer satisfaction and loyalty.

Izquierdo et al. (2005) developed a model in which, car repair and maintenance are tested as a case where long term customer relationship is frequentative. Path analysis is used to evaluate the association of customers' perception, market loyalty and market position. The hypotheses were evaluated using a path analysis, which examines the relationship between marketing activities and economic performance.

This model is proposed based on performance of the market and economic. The measures of proposed model are as follows (Izquierdo et al., 2005):

1) The position of Market

2) Customer Loyalty

3) Customer insight

4) Economic and market performance

The findings suggest that CRM implementation include attraction activities which are service quality, commercial practices and loyalty programs such as bonus, contact, satisfaction and complaints handling. This result in appropriate perception of customers leading to increasing customer loyalty and therefore, economic performance of the firm would be increased.

Feinberg and Kadam (2002) argue that emphasizing to online business rather than traditional way of business is necessary nowadays. So in this way, the usage of internet provides an opportunity for business to use it as a tool for CRM. According to their research, there are 42 different e-CRM features used by the retailers. The finding shows that there is significant relationship between CRM implementation on websites of the retailers and customer satisfaction which leads to customer loyalty. However all attributes of implemented CRM are not equal in terms of predicting the customer satisfaction and loyalty (Feinberg and Kadam, 2002).

\section{Critical Elements of CRM}

Four critical elements of CRM are to be examined in this study. These elements are interaction management, relationship development, customer service and employees' behavior.

\subsection{Interaction Management}

According to the Brown and Gulycz (2002), if an organization willing to make a stable relationship with its customers, there are different ways to have an interaction with them including interaction along touch points and distribution channels. The main purpose is to find out how and when the customers would like to interact with the organization (Prahalad and Ramaswamy, 2001). The interaction activities should be well customized and organized through the available touch points. The touch points provide in relation to the customers' profiles developed by data gathered from the former records of the customers. Peppers and Rogers (1997) stress that the touch points must be used for distribution of different products, services and communication with the customers. According to the works of Lindgreen et al. (2006) and Peppers et al. (1999), interaction management is implemented by a few methods such as getting customers' feedback and increase the interaction with customers by attractive ways such as using social network.

\subsection{Relationship Development}

According to Ford (1980), the study of relationship development primarily involves research into structures and processing of the relationship between customer and supplier. Hakansson and Snehota (1995) argue that the relationship development process concerns an interaction where connections have been developed between two parties.

The most important activity to achieve relationship development is known as monitoring of the relationship management process such as service or complaint management (Brown and Gulycz, 2002). This relationship processes include procedures, mechanisms, schedules, and activities in which the products and services have been delivered to customers (Christopher et al., 1991). The key performance indicators such as rate of retention, life time value of the customers, and customer satisfaction should be set by the organization (Brown and Gulycz, 2002). According to the works of Hanley (2008) and Lindgreen et al. (2006), relationship development can be made through commitment to convince customers that their feedback are taken seriously.

\subsection{Quality of Services}

According to Gee et al (2008) in an attempt to understand the factors that induce customer satisfaction, the concept 
of service quality is increasingly common in the literature. Studies show that service quality has a positive effect on consumer satisfaction and also has a significant relationship with customer loyalty, and the profitability of the firms. According to the works of Hanley (2008), the quality of services could be implemented by a few methods such as:

1) Meeting customer expectation of good service level and having many varieties of products.

2) Provide good quality products with reasonable price.

3) To handle the customer complains about the products and services tactfully.

\subsection{Behavior of the Employees}

An employee that conforms with organization behavior and value is likely to strengthen the connection between the consumer and the firm. A reverse pattern of effects is to be expected when the employee act through his/her own behavior. In these cases, a consumer may think that the organization actually does not deliver the symbolic benefits that $\mathrm{s} / \mathrm{he}$ had expected for and may evaluate the organization in a negative way. In other words, under circumstances such as the ones described, an employee will probably exert a strong impact on organization reputation and attitudes (Coulter, 2002). According to the works of Hanley (2008) and Coulter (2002), the effect of positive employees' behavior could be expressed by increasing speed of response to customer and ensure employees are friendly and respectful to customer.

\section{Purpose of Study}

The purpose of this study is to examine the impact of customer relationship management on customer satisfaction and customer loyalty. Base on the above literature review on various previous studies, several critical elements identified that link closely with customer satisfaction and loyalty are behavior of employee, quality of customer services, relationship development and interaction management. Therefore a conceptual framework is developed as illustrate in Figure 1.

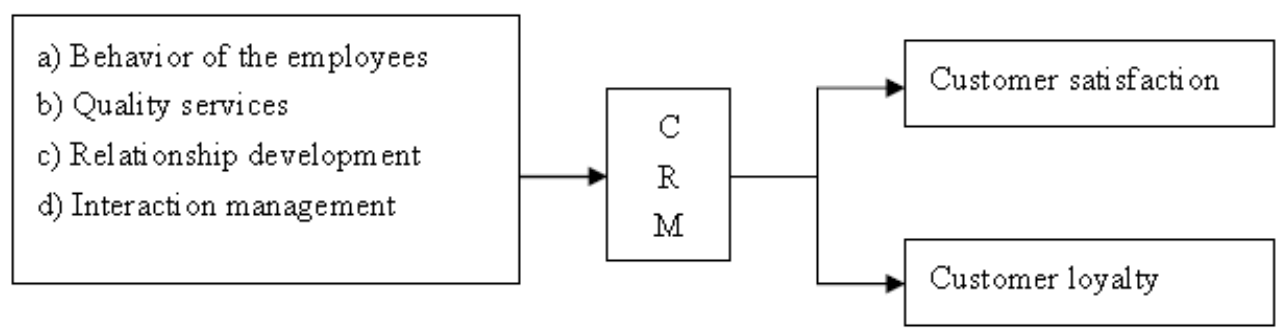

Figure 1. Conceptual framework

\section{Research Method}

In this study, quantitative research will be selected. It will distribute a set of questionnaires to collect data from the respondents. The collected data will be analysed through statistically using the SPSS software package. Inferential statistical analysis will be conducted in order to achieve the objectives of this study. The Likert scale rating is used for data collection. The Likert scale rating is a rating system in which the respondents indicate how strongly they agree with the questions or disagrees with them (Saunders et al., 2009). A Departmental Store in Iran, Tehran is chosen for this case study. The name of the organization is not disclosed as requested by the Departmental Store management team. Therefore, in this paper, the organization will be named as "ABC Company".

People who live in Tehran are subjects for this study. They are considered to be the appropriate subject for this research because they have experience in a wide range of shopping activities. They are also expected to be familiar with a variety of shopping activities that would help this study seeking better perception of the services provided by $\mathrm{ABC}$ Company. There are 300 usable survey forms returned by respondents out of total 500 survey forms that are distributed.

\section{Findings}

Research objectives are tested by using multiple regression analysis as shown in Table $1 \& 2$. 
Table 1. Multiple regression analysis for CRM on customer satisfaction

\begin{tabular}{lllll}
\hline Model & \multicolumn{1}{c}{$\mathrm{R}$} & $\mathrm{R}$ Square & Adjusted R Square & \multicolumn{2}{l}{ Std. Error of the Estimate } \\
\hline 1 & $.432^{\mathrm{a}}$ & .186 & .175 & \multicolumn{2}{c}{.55137} \\
\hline & \multicolumn{3}{l}{ Significant } \\
\hline CRM Elements & & $\mathrm{B}$ & .001 \\
\hline Behavior of the employees & .363 & .240 \\
Quality of services and products & .100 & .004 \\
Relationship development & .158 & .481 \\
Interaction management & & -.032 & \\
\hline
\end{tabular}

Base on the Table 1, it is found that CRM elements overall has positive relationship with customer satisfaction $(\mathrm{R}=0.432)$. However, base on the adjusted $\mathrm{R}$ square value of 0.175 , these elements only contribute $17.5 \%$ to dependent variables. Behavior of the employees and relationship development give significant impact to customer satisfaction. It is clear that in dependent variable with higher level of $\beta$ has higher impact on dependent variable. In this study result reveal that the factor of Behavior of the employees $(\beta=.368$, sig<.01) is most influential factor and relationship development with the customers $(\beta=.100, \operatorname{sig}<.05)$ is ranked second. The rest of the elements did not show any significant contribution.

Table 2. Multiple regression analysis for CRM on customer loyalty

\begin{tabular}{lllll}
\hline Model & \multicolumn{1}{c}{$\mathrm{R}$} & $\mathrm{R}$ Square & Adjusted R Square & \multicolumn{2}{l}{ Std. Error of the Estimate } \\
\hline 1 & $.442^{\mathrm{a}}$ & .195 & .184 & .56160 \\
\hline \\
\hline CRM Elements & & $\mathrm{B}$ & Significant \\
\hline Behavior of the employees & & .575 & .000 \\
Quality of services and products & & .143 & .099 \\
Relationship development & & .032 & .565 \\
Interaction management & -.045 & .329 \\
\hline
\end{tabular}

Base on the Table 2, it is found that CRM elements overall has positive relationship with customer satisfaction $(\mathrm{R}=0.442)$. However, base on the adjusted $\mathrm{R}$ square value of 0.184 , these elements only contribute $18.4 \%$ to dependent variables. Out of all CRM element measured, only Behavior of the employees give significant impact to customer satisfaction. The results of this study reveal that only behavior of the employees $(\beta=.575, \operatorname{sig}<.01)$ element is most influential factor and the rest of the element did not show any significant impact on customer loyalty.

\section{Discussion and Conclusion}

The above results clearly show that CRM does have a positive relationship with the dependent variables (customer satisfaction and loyalty). However, not all elements have significant impact on the dependent variables. The behavior of the employees and relationship development found to contribute most to customer satisfaction. This result confirms the findings of previous studies (Coulter, 2002; Brown \& Gulycz, 2002; Hanley, 2008). The outcome of the findings implicate that store employee who has good relation with customer will increase customer satisfaction. Behavior of the employees is also play significant role in increasing customer loyalty. This findings are also supported by several previous studies (Hanley, 2008; Szczepańska \& Gawron, 2011).

The organization must put emphasis in the two elements which are behavior of employees and relationship development. Employees are expect not merely be polite and courteous towards their customer, but most importantly must have the product knowledge and communication skills that can create a relationship with the customers Hanley (2008) and Coulter (2002) further stress that positive employees' behavior is vital in sustaining customers' loyalty. Employees must be trained to response to the customers' needs in an appropriate speed. They 
must also able to show concern and care to the customers. Behavior change can only be done if management team is serious in investing in their human capital. This can only be done through series of training and developmental programs for the employees. By improving the competencies of employees in this area will definitely improve the overall service quality of the organization. Organization must also constantly keep their employees motivated because highly motivated people would definitely able provide better services.

Adebanjo (2003) argued that analytical CRM tools can be used in increasing relationship of the customers through analyzing the captured data from customers. Analytical CRM is used to analyzing customer inquiries and behavior to support the decision making for the services. Furthermore, Hanley (2008) and Lindgree $\mathrm{n}$ et al. (2006) stress that relationship development can be improved by a few methods such as:

1) Inform customers about promotions, discounts and other facilities of the organizations.

2) Encourage customers to purchase more by showing appreciation.

3) To convince customers that their feedback are taken seriously.

This study only focuses on one organization in a country in Middle-East. Therefore the result of study cannot be generalized to other part of the world. However, a comparative study can be done in future to look in the differences of two different regions or countries on the CRM practices that effect customer satisfaction and loyalty.

CRM is the most efficient approach in maintaining and creating relationships with customers. CRM is not only pure business but also ideate strong personal bonding within people. Development of this type of bonding drives the business to new levels of success. Once this personal linkage is built, it is very easy for organization to identify the actual needs of customers and to serve them in a better way. It is a belief that the more sophisticated strategies involved in implementing CRM, the more fruitful is the business. Organizations must consider seriously in investing on tools for implementing CRM systems in their workplace.

\section{Acknowledgements}

The authors would like to thanks the Malaysian Ministry of Higher Education, Universiti Teknologi Malaysia (Vot. 07J89) for supporting this research and publication.

\section{References}

Adebanjo, D. (2003). Classifying and selecting e-CRM applications: An analysis-based proposal. Management Decision, 41(5/6), 570-577. http://dx.doi.org/10.1108/00251740310491517

Baker, S. (2003). New consumer marketing: Managing a living demand system. England: Wiley.

Bhattacharya, A. (2011). Preeminent Analysis of Customer Relationship Management (CRM). International Journal of Research in Management \& Technology, 1(1), 45-51.

Bohling, T., Bowman, D., LaValle, S., Mittal, V., Narayandas, D., Ramani, G., \& Varadarajan, R. (2006). CRM Implementation: Effectiveness Issues and Insights. Journal of Service Research, 9, 184-194. http://dx.doi.org/10.1177/1094670506293573

Bowen, J. T., \& Chen, S. L. (2001). The Relationship Between Customer Loyalty and Customer Satisfaction, International Journal of Contemporary Hospitality Management, 1(2), 213-217. http://dx.doi.org/10.1108/09596110110395893

Brown, S. A., \& Gulycz, M. (2002). Performance Driven CRM: How to make your customer relationship management visions a reality. Ontario: John Wiley.

Christopher, M., Payne, A., \& Ballantyne, D. (1991). Relationship Marketing. Oxford' Butterworth-Heinemann.

Coulter, K. S., \& Coulter, R. A. (2002). Determinants of trust in a service provider: the moderating role of length of relationship. Journal of Service Marketing, 16, 35-50. http://dx.doi.org/10.1108/08876040210419406

Dowling, G. (2002). Customer Relationship Management: In B2C Markets, Often Less Is More. California Management Review, 44(3), 121-137. http://dx.doi.org/10.2307/41166134

Faed, A. (2010). A conceptual framework for E-loyalty in Digital Business Environment. $4^{\text {th }}$ IEEE DEST, $547-552$.

Feinberg, R., \& Kadam, R. (2002). E-CRM Web service attributes as determinants of customer satisfaction with retail Web sites. International Journal of Service Industry Management, 13(5), 432-451. http://dx.doi.org/10.1108/09564230210447922

Gee, R., Coates, G., \& Nicholson, M. (2008). Understanding and profitably managing customer loyalty. 
Marketing Intelligence \& Planning, 26(4), 359-374. http://dx.doi.org/10.1108/02634500810879278

Hanley, S, \& Leahy, R. (2008). The effectiveness of relationship marketing strategies in department stores. International Journal of Business Management, 3(10), 133-140.

Izquierdo, C. C., Cilla'n, J. G., \& Gutie'rrez, S. S. (2005). The impact of customer relationship marketing on the firm performance: a Spanish case. Journal of Services Marketing, 19(4), 234-244. http://dx.doi.org/10.1108/08876040510605262

Jain, D., \& Singh, S. (2002). Customer lifetime value research in marketing: A review and future directions. Journal of Interactive Marketing, 16(2), 34-46. http://dx.doi.org/10.1002/dir.10032

Khaligh, A., Miremadi, A., \& Aminilari, M. (2012). The Impact of eCRM on Loyalty and Retention of Customers in Iranian Telecommunication Sector. International Journal of Business Management, 7(2), $150-162$.

Kim et al. (2003). A model for evaluating the effectiveness of CRM using the balanced scorecard. Journal of Interactive Marketing, 17(2), 5-19. http://dx.doi.org/10.1002/dir.10051

Kotler, P., \& Armstrong, G. (2011). Principles of Marketing (14th ed.). New Jersey: Prentice Hall.

Lindgreen, A., Palmer, R., Vanhamme, J., \& Wouters, J. (2006). A relationship management assessment tool: Questioning, identifying, and prioritizing critical aspects of customer relationships. Industrial Marketing Management, 35(1), 57-71. http://dx.doi.org/10.1016/j.indmarman.2005.08.008

Mohsan, F., Nawaz, M. M., Khan, M. S., Shaukat, Z., \& Aslam, N. (2011). Impact of Customer Satisfaction on Customer Loyalty and Intentions to Switch: Evidence from Banking Sector of Pakistan. International Journal of Business and Social Science, 2(16), 230-245.

Peppers, D., \& Rogers, M. (1997). Enterprise one to one. New York' Bantam Doubleday Dell Publishing Group.

Saunders, M., Lewis, P., \& Thornhill, A. (2009). Research methods for business student (5th ed.). Harlow, England: Prentice Hall.

Sivadass, E., \& Baker-Prewitt, J. L. (2000). An Examination of the Relationship between Service Quality, Customer Satisfaction, and Store Loyalty. International Journal of Retail \& Distribution Management, 28(2), 73-82. http://dx.doi.org/10.1108/09590550010315223

Szczepańska, K., \& Gawron, P. P. (2011). Changes in Approach to Customer Loyalty. Contemporary Economics, 5(1), 60-69. http://dx.doi.org/10.5709/ce.1897-9254.5

Wang, Y., \& Lo, H. P. (2004). An integrated framework for customer value and customer-relationship management performance: a customer-based., perspective from China. Managing Service Quality, 14(2/3), 169-182. http://dx.doi.org/10.1108/09604520410528590

Zineldin, M. (2006). The royalty of loyalty: CRM, quality and retention. Journal of Consumer Marketing, 23(7), 430-437. http://dx.doi.org/10.1108/07363760610712975

\section{Copyrights}

Copyright for this article is retained by the author(s), with first publication rights granted to the journal.

This is an open-access article distributed under the terms and conditions of the Creative Commons Attribution license (http://creativecommons.org/licenses/by/3.0/). 